\title{
Robust bifunctional aluminium-salen catalysts for the preparation of cyclic carbonates from carbon dioxide and epoxides
}

\author{
Yuri A. Rulev ${ }^{1}$, Zalina Gugkaeva1 ${ }^{1}$, Victor I. Maleev¹, Michael North ${ }^{*}$ \\ and Yuri N. Belokon*1
}

\section{Full Research Paper}

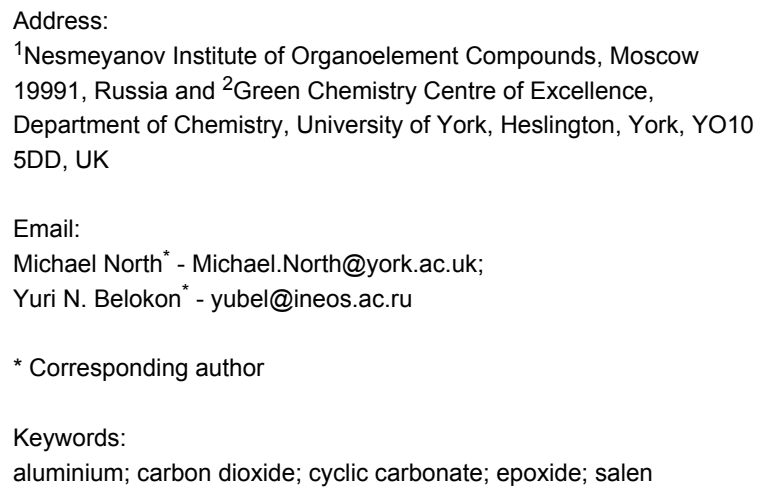

${ }^{1}$ Nesmeyanov Institute of Organoelement Compounds, Moscow 19991, Russia and ${ }^{2}$ Green Chemistry Centre of Excellence, Department of Chemistry, University of York, Heslington, York, YO10 5DD, UK

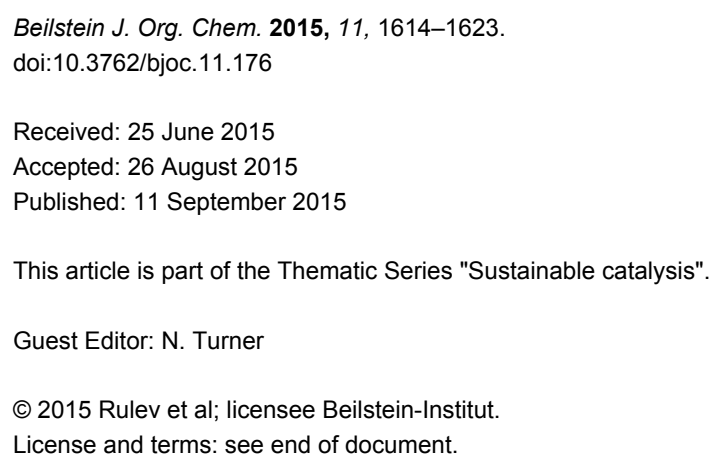

\section{Abstract}

Two new one-component aluminium-based catalysts for the reaction between epoxides and carbon dioxide have been prepared. The catalysts are composed of aluminium-salen chloride complexes with trialkylammonium groups directly attached to the aromatic rings of the salen ligand. With terminal epoxides, the catalysts induced the formation of cyclic carbonates under mild reaction conditions $\left(25-35{ }^{\circ} \mathrm{C} ; 1-10\right.$ bar carbon dioxide pressure). However, with cyclohexene oxide under the same reaction conditions, the same catalysts induced the formation of polycarbonate. The catalysts could be recovered from the reaction mixture and reused.

\section{Introduction}

Carbon dioxide is a renewable and inexpensive carbon source, so great efforts have been directed at developing novel methods for the valorization of this abundant raw material [1]. One way of achieving this goal is to produce cyclic carbonates or polycarbonates from carbon dioxide and the corresponding epoxides (Scheme 1). Cyclic carbonates are an important class of solvents [2] and starting materials in organic synthesis [3-6].

Although a significant array of catalysts have been developed for the production of cyclic carbonates [7-9] and polycarbon-

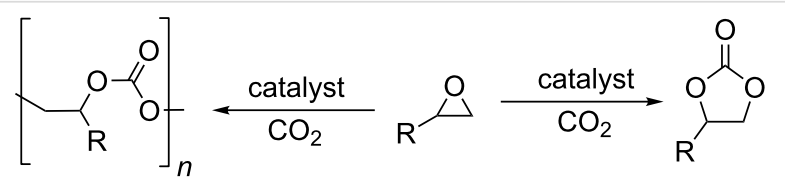

Scheme 1: Synthesis of cyclic and polycarbonates.

ates [10,11] from carbon dioxide and epoxides, the most developed and privileged set of catalysts are based on Lewis acidic metal-salen complexes. In particular, cobalt(III) and 
chromium(III) complexes were found to be highly efficient for polycarbonate production [12]. Further modification of the salen moiety by the introduction of basic or ammonium salts through alkyl spacers attached to the salen aromatic rings led to the formation of a family of bifunctional catalysts possessing both Lewis acid and nucleophilic catalysis capability (via the anion in the case of catalysts containing ammonium salts), with a concomitant increase in their activity $[12,13]$. Recently, more environmentally benign aluminium-based complexes, including salen complexes, have been introduced to catalyse cyclic carbonate production [14]. The performance of these catalysts was also greatly improved by the introduction of bifunctional versions of the catalyst system, combining an electrophilic aluminium centre with an ammonium cation/nucleophilic-counteranion combination within the framework of a single catalytic species as reported by North [15], Liu and Darensbourg [14], and $\mathrm{Lu}$ [16] (Figure 1).

Unfortunately, the bifunctional derivatives with an alkyl spacer are not very stable at higher temperatures because of the wellknown ammonium salt decomposition pathways including: Zaitsev and Hoffman type eliminations [17-19] and retroMenschutkin reactions [20-23]. We reasoned that the direct introduction of ammonium moieties onto the aromatic rings of the salen ligands (as in structures $\mathbf{1}$ and $\mathbf{2}$ ) would greatly stabilize the whole structure by reducing the number of $\mathrm{sp}^{3}$ hybridized carbon atoms attached to the nitrogen atoms of the ammonium salts and increasing the steric hindrance around the ammonium salts. Herein, we report the synthesis of two aluminium-salen complexes incorporating quaternary ammonium salts directly attached to the salen ligand and their catalytic activities for the coupling of epoxides and carbon dioxide under solvent free conditions. Catalyst recycling experiments are also reported and show the robustness of this system.

\section{Results and Discussion}

The preparation of salen ligands $8 \mathbf{a}$ and $\mathbf{8 b}$ was conducted according to Scheme 2, starting from tert-butylphenol, which was formylated and then nitrated to produce 5-nitro-3-(tertbutyl)salicylaldehyde (5) [24-27]. 5-N,N-Dimethylamino-3(tert-butyl)salicylaldehyde (6) was prepared directly from $\mathbf{5}$, using a literature procedure $[28,29]$. The salen ligand 7 was then obtained in high yield by condensation with $(R, R)$-cyclohexanediamine, according to a known technique [30]. Ligand 7 was efficiently alkylated under mild reaction conditions using either methyl iodide or benzyl bromide, giving the corresponding

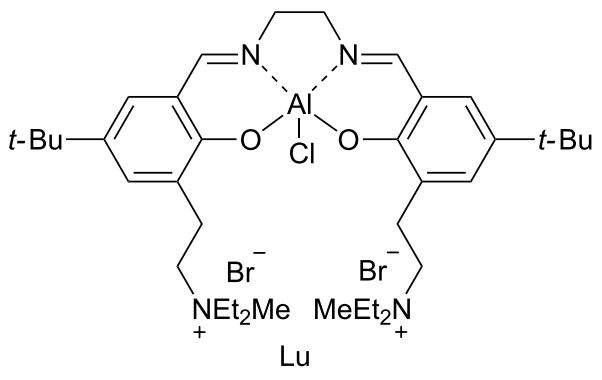

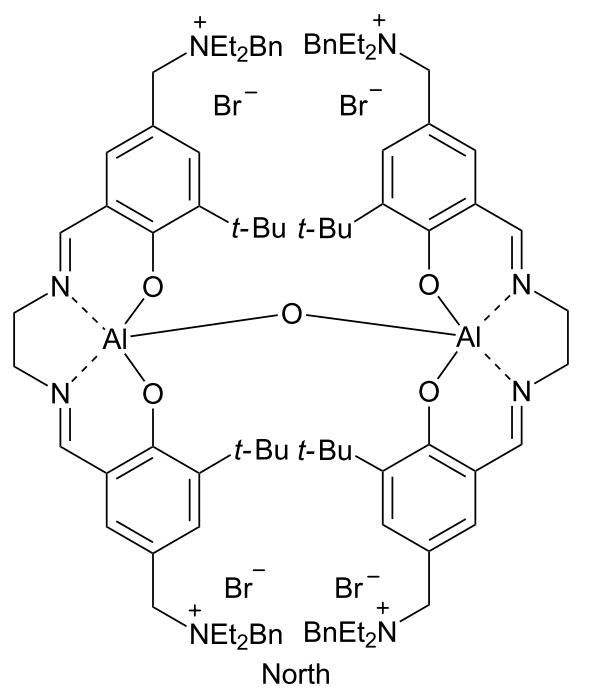

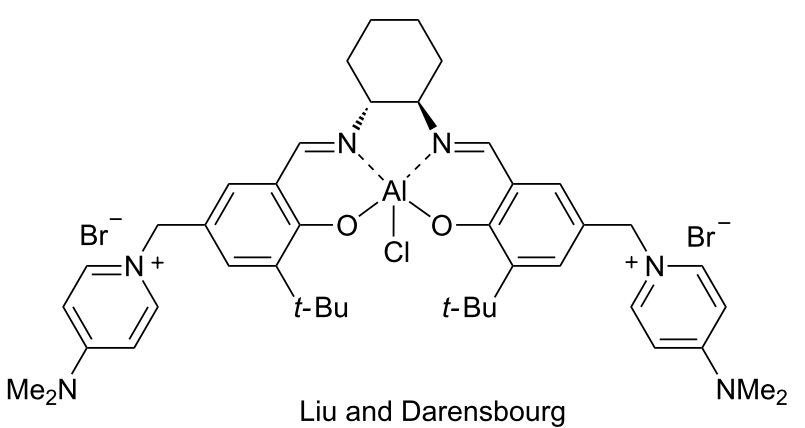

Liu and Darensbourg

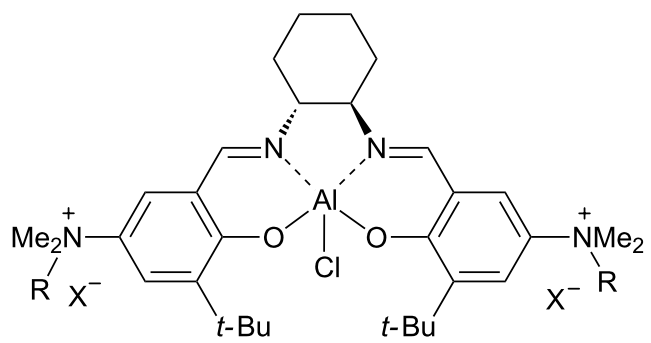

(1) $\mathrm{R}=\mathrm{Me}, X=\mathrm{I}$

(2) $R=B n, X=B r$

present work 
positively charged salen ligands $\mathbf{8 a}$ and $\mathbf{8 b}$ in 95 and $78 \%$ yields respectively. The aluminium-salen complexes were prepared by treating $\mathbf{8 a}$ and $\mathbf{8 b}$ with diethylaluminium chloride (Scheme 3), affording complexes $\mathbf{1}$ and $\mathbf{2}$ in $96 \%$ and $91 \%$ yields respectively. These complexes could be used without any additional purification.<smiles>CC(C)(C)c1ccccc1O</smiles>

3<smiles>C[N+](C)(C)CCc1ccccc1</smiles><smiles>O=Cc1cccc(I)c1O</smiles>

4

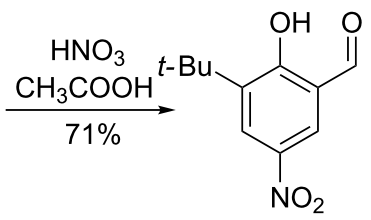

5<smiles>COC(=O)OCC(=O)OCc1cc(N(C)C)cc(C=O)c1O</smiles>

6

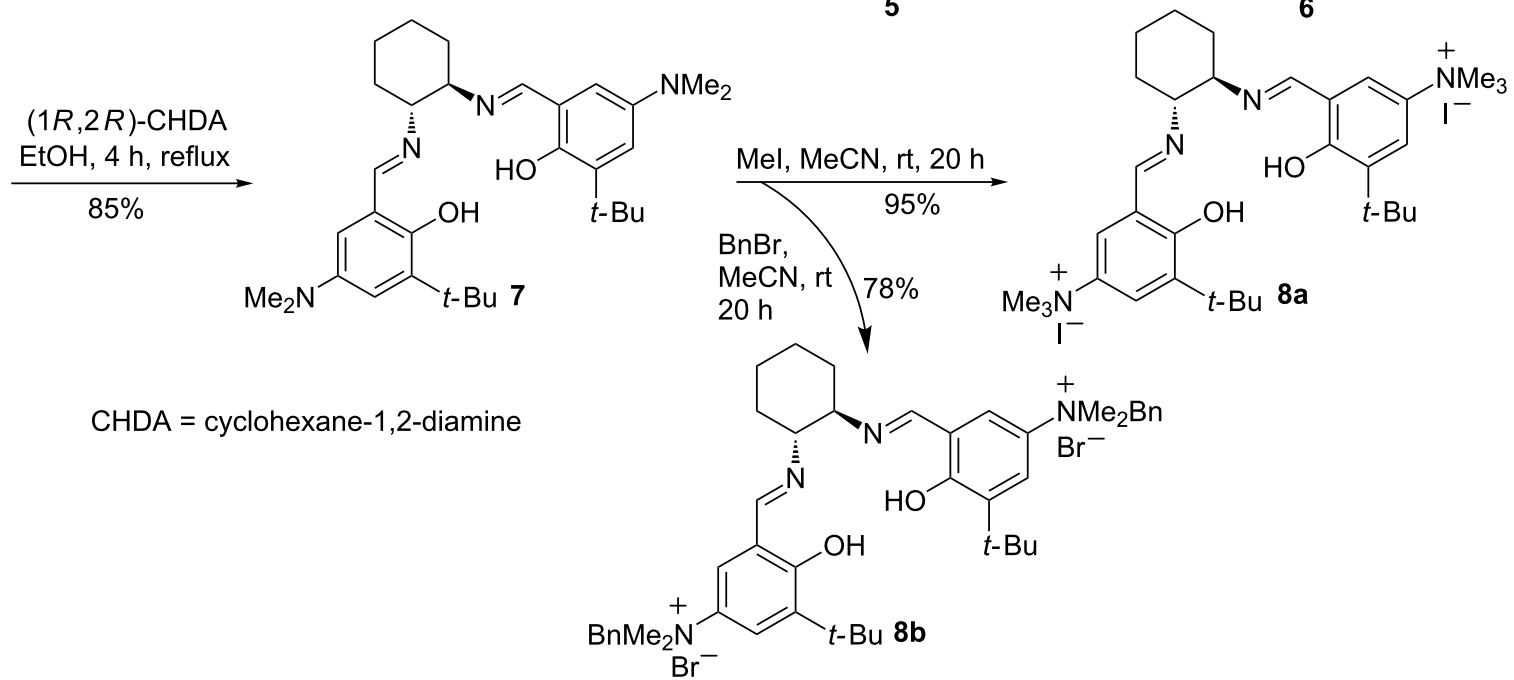

Scheme 2: Synthesis of salen ligands $\mathbf{8 a}$ and $\mathbf{8 b}$.

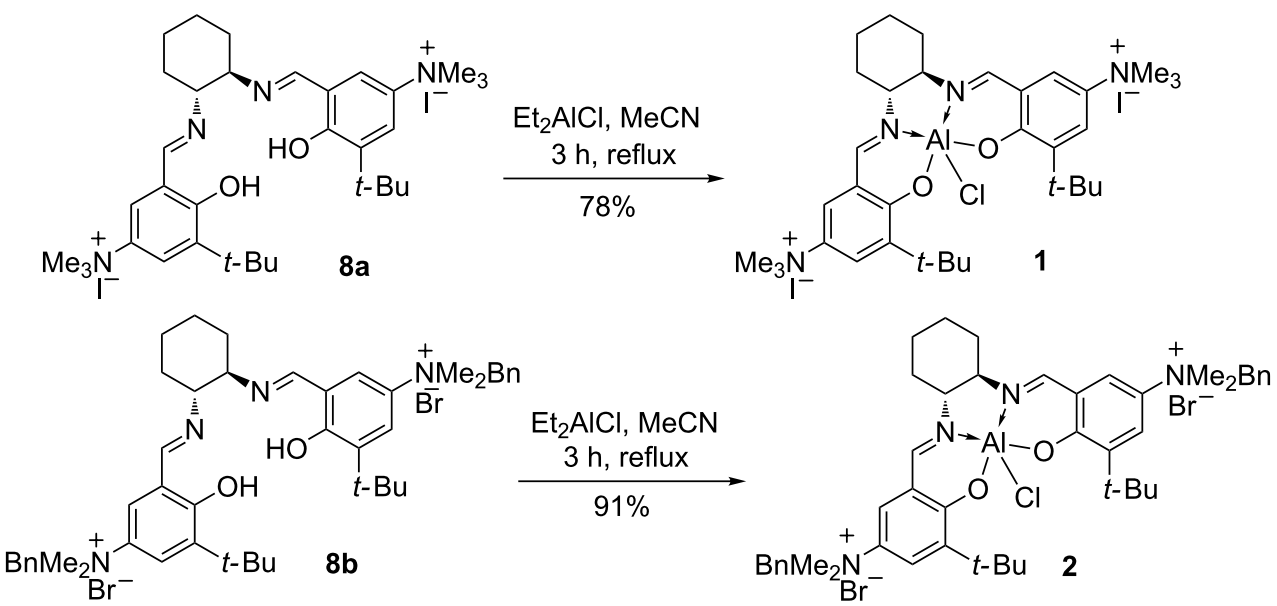<smiles>CC(C)(C)c1cc(C=N[C@H]2CCCC[C@H]2N=Cc2cc(C(C)(C)C)cc(C(C)(C)C)c2O)c(O)c(C(C)(C)C)c1</smiles> 
Styrene oxide was used as a model substrate to test the catalytic efficiency of complexes $\mathbf{1}$ and $\mathbf{2}$ in the coupling reaction with carbon dioxide. Table 1 summarizes the experimental results. It is apparent from the data that both catalysts are effective at promoting the coupling reaction even at room temperature and 1 bar of carbon dioxide pressure (Table 1, entries 1-4 and 10-12). However, complex 2 was a better catalyst, affording $83 \%$ conversion of styrene oxide to the corresponding cyclic carbonate after 24 hours, whereas complex 1 gave only $47 \%$ conversion under the same conditions (Table 1, entries 4 and 12). Increasing either the temperature of the reaction or the carbon dioxide pressure had positive effects on the catalytic performance (Table 1, entries 8, 9 and 13).

Furthermore, the performance of catalyst 1 could be improved by adding one equivalent of water and triethylamine relative to the catalyst loading (Table 1, entries 5-7). Presumably, some of complex 1 was converted into a highly active oxygen-bridged aluminium complex in situ, as shown in Scheme 4. High activities for this type of dinuclear complexes have been reported before [31].

In order to prove the bifunctional nature of our catalysts, aluminium complex 10 was prepared (Scheme 3) using 3,5-di(tert-butyl)salicylaldehyde as a starting material. It was found that this catalyst was almost inactive in the reaction of styrene oxide with carbon dioxide (Table 1, entry 14). After addition of tetrabutylammonium iodide ( $5 \mathrm{~mol} \%$ ) as a cocatalyst, the conversion was increased to $80 \%$ (Table 1 , entry 15), which was close to the performance of catalyst 2 (Table 1, entry 12). This supports the hypothesis that complexes $\mathbf{1}$ and $\mathbf{2}$ are bifunctional catalysts in which both the

\begin{tabular}{|c|c|c|c|c|c|c|}
\hline Entry & Catalyst & Catalyst loading (mol \%) & Time $(\mathrm{h})$ & Pressure (bar) & Temperature $\left({ }^{\circ} \mathrm{C}\right)$ & Conversion (\%) \\
\hline 1 & 1 & 0.2 & 24 & 1 & 25 & 8 \\
\hline 2 & 1 & 1 & 24 & 1 & 25 & 16 \\
\hline 3 & 1 & 2 & 24 & 1 & 25 & 40 \\
\hline 4 & 1 & 2.5 & 24 & 1 & 25 & 47 \\
\hline $5^{b}$ & 1 & 2.5 & 3 & 1 & 25 & 8 \\
\hline $6^{b}$ & 1 & 2.5 & 6 & 1 & 25 & 17 \\
\hline $7^{b}$ & 1 & 2.5 & 24 & 1 & 25 & 72 \\
\hline 8 & 1 & 2.5 & 24 & 10 & 25 & 70 \\
\hline 9 & 1 & 2.5 & 24 & 10 & 35 & 100 \\
\hline 10 & 2 & 2.5 & 3 & 1 & 25 & 14 \\
\hline 11 & 2 & 2.5 & 6 & 1 & 25 & 43 \\
\hline 12 & 2 & 2.5 & 24 & 1 & 25 & 83 \\
\hline 13 & 2 & 2.5 & 24 & 10 & 25 & 100 \\
\hline 14 & 10 & 2.5 & 24 & 1 & 25 & 5 \\
\hline $15^{c}$ & 10 & 2.5 & 24 & 1 & 25 & 80 \\
\hline
\end{tabular}

${ }^{\mathrm{a}}$ In neat styrene oxide. ${ }^{\mathrm{b}}$ One equivalent of $\mathrm{H}_{2} \mathrm{O}$ and $\mathrm{Et}_{3} \mathrm{~N}$ were added to the catalyst. ${ }^{\mathrm{c}}$ With $5 \mathrm{~mol} \%$ tetrabutylammonium iodide as cocatalyst.

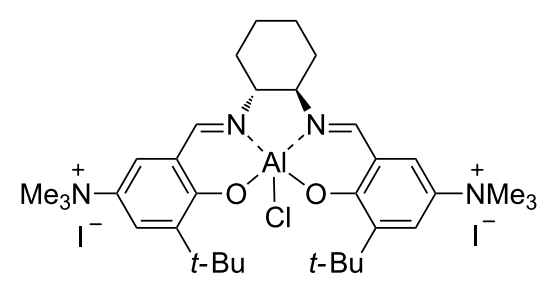<smiles></smiles>

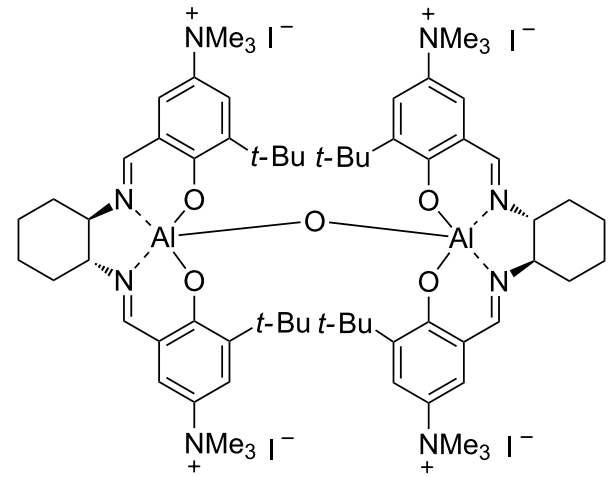


aluminium centre and the ammonium halide play important catalytic roles.

After finding the optimal reaction conditions for each catalyst, both complexes $\mathbf{1}$ and $\mathbf{2}$ were tested with a range of epoxides. These experiments were carried out without added water to allow direct comparison of the two catalysts and to avoid complicating the reaction system. The results are summarized in Table 2. Both catalysts proved to be efficient for coupling both aromatic and aliphatic substrates. In all cases reported in Table 2, cyclic carbonate, catalyst and unreacted epoxide (for entries 10 and 11) were the only species detected by ${ }^{1} \mathrm{H}$ NMR spectroscopy of the crude reaction product prior to purification by column chromatography. The moderate yield for propylene oxide (Table 2, entry 6 ) can be explained by volatility of the starting material under the reaction conditions.

No cyclic carbonate was detected when cyclohexene oxide was used as substrate (Table 3, entries 1-5) and almost no conversion at all was detected in the reaction promoted by complex 1 (Table 3, entries 1 and 2). Catalyst 2 was more active and catalysed the synthesis of the corresponding polycarbonate with $64 \%$ conversion at 10 bar (Table 3, entry 4) and $92 \%$ at 35 bar carbon dioxide pressure (Table 3, entry 5). Previous reports have indicated that in the presence of a cocatalyst, aluminium-salen complexes can catalyse the formation of either cyclic [32] or polycarbonate [33,34] from cyclohexene oxide, depending on the exact structure of the catalyst and cocatalyst. However, this is the first report of a one-component aluminium-salen-based catalyst for polycyclohexene carbonate synthesis.

MALDI-TOF mass-spectra data (Figure 2) showed that the polycarbonate consisted of a mixture of oligomers with a range
Table 2: Coupling of $\mathrm{CO}_{2}$ and various epoxides promoted by complexes $\mathbf{1}$ and 2 . $^{\text {a }}$<smiles>[R]C1COC(=O)O1</smiles>

\begin{tabular}{ccccc}
\hline Entry & Catalyst & $\mathrm{R}$ & Conversion $^{\mathrm{b}}(\%)$ & Yield $^{\mathrm{C}}(\%)$ \\
\hline 1 & $\mathbf{1}$ & $\mathrm{Ph}$ & 100 & 62 \\
2 & $\mathbf{1}$ & $\mathrm{CH}_{2} \mathrm{OPh}$ & 100 & 78 \\
3 & $\mathbf{1}$ & $p-\mathrm{ClPh}$ & 100 & 95 \\
4 & $\mathbf{1}$ & $\mathrm{Bu}$ & 100 & 80 \\
5 & $\mathbf{1}$ & $\mathrm{Et}$ & 100 & 78 \\
6 & $\mathbf{1}$ & $\mathrm{Me}$ & 100 & 52 \\
7 & $\mathbf{1}$ & $\mathrm{CH}_{2} \mathrm{Cl}$ & 100 & 82 \\
8 & $\mathbf{1}$ & $\mathrm{CH}_{2} \mathrm{OH}$ & 100 & 85 \\
9 & $\mathbf{2}$ & $\mathrm{Ph}$ & 100 & 80 \\
10 & $\mathbf{2}$ & $\mathrm{CH}_{2} \mathrm{OPh}$ & 64 & 56 \\
11 & $\mathbf{2}$ & $p-\mathrm{ClPh}$ & 99 & 84 \\
12 & $\mathbf{2}$ & $\mathrm{Bu}$ & 100 & 60 \\
13 & $\mathbf{2}$ & $\mathrm{Et}$ & 100 & 71 \\
14 & $\mathbf{2}$ & $\mathrm{Me}$ & 100 & 88 \\
15 & $\mathbf{2}$ & $\mathrm{CH}_{2} \mathrm{Cl}$ & 100 & 80 \\
16 & $\mathbf{2}$ & $\mathrm{CH}_{2} \mathrm{OH}$ & 100 & 76 \\
\hline
\end{tabular}

aReaction conditions for catalyst 1 : solvent free, 10 bar pressure of $\mathrm{CO}_{2}, 35^{\circ} \mathrm{C}, 24 \mathrm{~h}$; for catalyst 2: solvent free, 10 bar pressure of $\mathrm{CO}_{2}$, $25^{\circ} \mathrm{C}, 24 \mathrm{~h}$. ${ }^{\mathrm{b}}$ Determined by ${ }^{1} \mathrm{H}$ NMR spectroscopy of the unpurified product. ${ }^{\mathrm{C}} \mathrm{After}$ purification by column chromatography.

of monomer units ( $n$ from 4 to 10 ) with the maximum intensity at $n=6$. Both ends of the polymer chain are capped with alcohol groups, suggesting that chain-transfer to adventitious moisture occurred during the polymerisation. GPC data (Figure 3) was consistent with the MALDI-TOF data, showing that most of the polymer has a molecular weight between 300

Table 3: Addition $\mathrm{CO}_{2}$ to cyclohexene oxide. ${ }^{\mathrm{a}}$

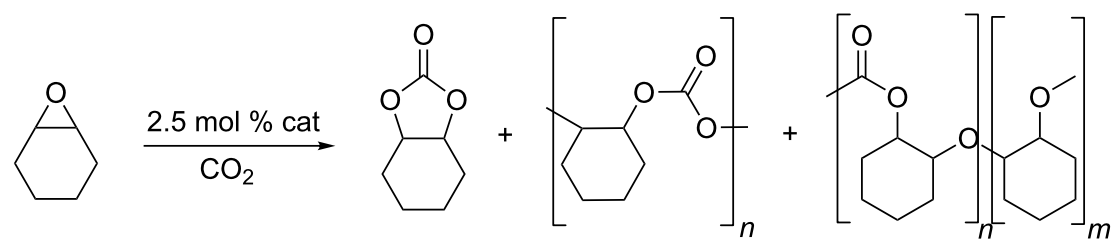

\begin{tabular}{|c|c|c|c|c|c|c|}
\hline Entry & Catalyst & Pressure (bar) & Time $(\mathrm{h})$ & Conversion (\%) & Polycarbonate (\%) & Polyether linkages (\%) \\
\hline 1 & 1 & 10 & 24 & 6 & 6 & - \\
\hline 2 & 1 & 10 & 111 & 11 & 11 & - \\
\hline 3 & 2 & 10 & 24 & 8 & 8 & - \\
\hline $4^{b}$ & 2 & 10 & 96 & 64 & 57 & 5 \\
\hline $5^{b}$ & 2 & 35 & 96 & 92 & 85 & 7 \\
\hline
\end{tabular}

aNeat cyclohexene oxide, temperature: for catalyst $1,35^{\circ} \mathrm{C}$; for catalyst $2,25^{\circ} \mathrm{C}$, only traces of cyclic carbonates were detected. ${ }^{\mathrm{b}} \mathrm{The}$ ratio of polycarbonate/polyether was determined from the ${ }^{1} \mathrm{H}$ NMR spectrum [11]. 


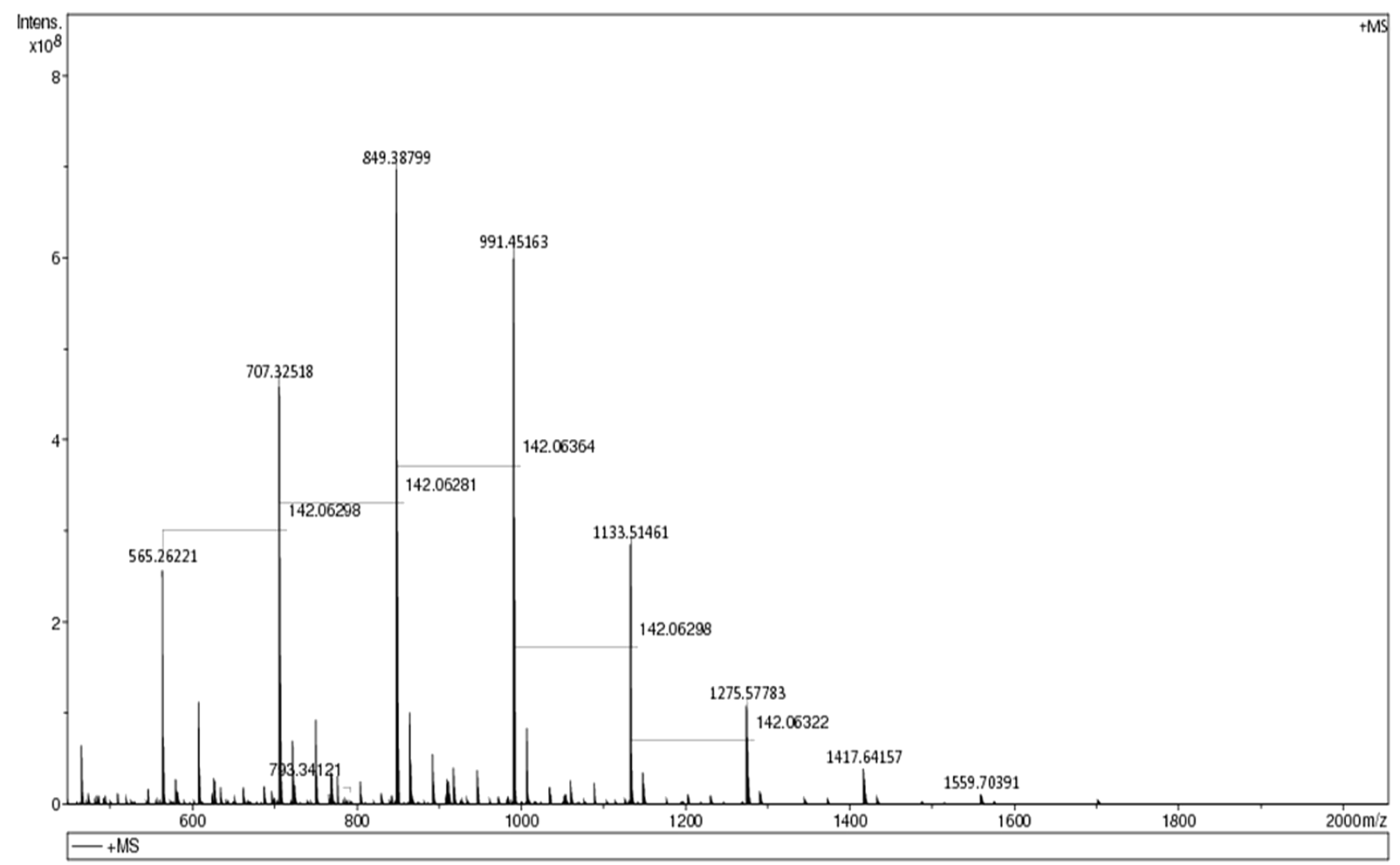

Figure 2: MALDI-TOF spectrum of poly(hexene carbonate) prepared using catalyst 2. The peak at 565 Daltons corresponds to four ring-opened cyclohexene oxide units, three $\mathrm{CO}_{2}$ units, 2 hydrogens (to cap the two terminal oxygens) and a sodium ion. The other peaks are then separated by 142 Daltons corresponding to an additional ring-opened cyclohexene oxide and carbon dioxide.

and 1000 Daltons. This type of low molecular weight polycarbonate-polyol is currently attracting much interest associated with its use in sustainable polyurethanes [35].

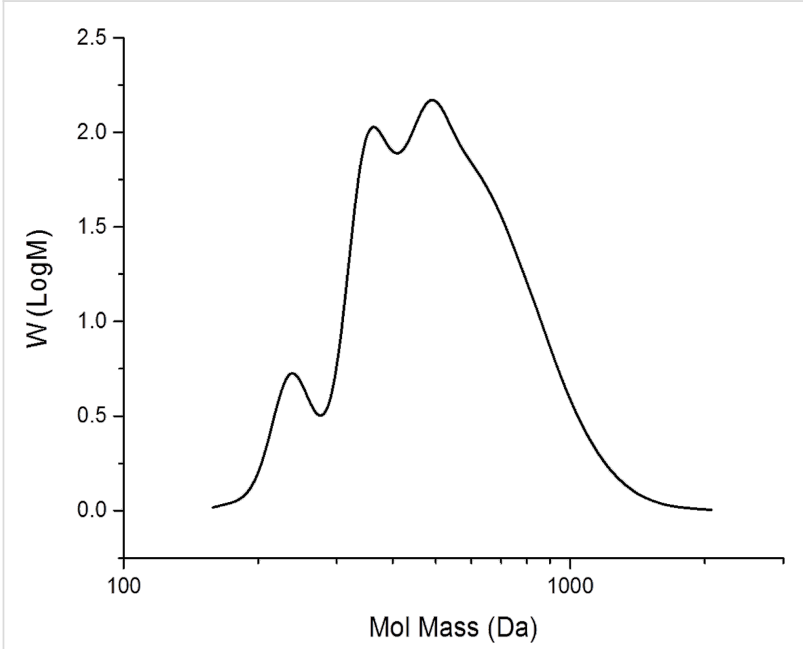

Figure 3: GPC trace of poly(cyclohexene carbonate) prepared using catalyst 2. The chromatogram was obtained in THF and is referenced to polystyrene standards.
To show the stability of our catalytic system, catalyst 1 was reused three times. For this purpose the catalyst was precipitated from the reaction mixture by the addition of ether followed by filtration. The catalyst was then dried in vacuo and then reused. The results are summarized in Table 4 . As can be seen, there were no significant losses of catalytic activity observed after three catalytic cycles.

Table 4: The catalytic activity of recovered catalyst 1.
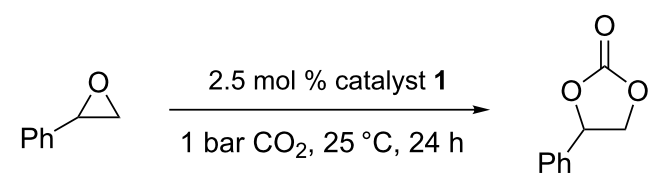

\begin{tabular}{cc}
\hline Cycle & Conversion \\
\hline 1 & 47 \\
2 & 45 \\
3 & 43
\end{tabular}




\section{Conclusion}

In conclusion, we have developed two new, bifunctional aluminium(salen) catalysts with quaternary ammonium groups directly attached to the aromatic rings. The catalytic system showed high activity in cyclic carbonate formation with a range of substrates. The bifunctional nature of our catalysts was demonstrated by comparing their performance with similar nonmodified aluminium complex 10. In contrast to previously reported aluminium-salen complexes, catalysts $\mathbf{1}$ and $\mathbf{2}$ produce polycarbonate rather than cyclic carbonate from cyclohexene oxide.

\section{Experimental Materials}

Commercial reagents were used as received unless stated otherwise. Column chromatography was performed using Silica Gel Kieselgel 60 (Merck).

\section{Instrumentation}

${ }^{1} \mathrm{H}$ NMR and ${ }^{13} \mathrm{C}$ NMR spectra were recorded on Bruker Avance 300 and Bruker Avance III-400 (operating at 300 and $400 \mathrm{MHz}$ for protons, respectively) spectrometers. Optical rotations were measured on a Perkin-Elmer 341 polarimeter in a 5 -cm cell. Melting points were determined in open capillary tubes and are uncorrected. Mass spectra were recorded at the University of York Mass Spectrometry Service Unit using ESI and MALDI ionization methods. GPC was carried out using a set (PSS SDV High) of 3 analytical columns $(300 \times 8 \mathrm{~mm}$, particle diameter $5 \mu \mathrm{m}$ ) of $1000,10^{5}$ and $10^{6} \AA$ pore sizes, plus guard column, supplied by Polymer Standards Service $\mathrm{GmbH}$ (PSS) installed in a PSS SECcurity GPCsystem. Elution was with tetrahydrofuran at $1 \mathrm{~mL} / \mathrm{min}$ with a column temperature of $23{ }^{\circ} \mathrm{C}$ and detection by refractive index. $20 \mu \mathrm{L}$ of a $1 \mathrm{mg} / \mathrm{mL}$ sample in THF was injected for each measurement and eluted for 40 minutes. Calibration was carried out in the molecular weight range $400-2 \times 10^{6}$ Da using ReadyCal polystyrene standards supplied by Sigma-Aldrich.

\section{General procedures for compounds (4-10) 3-(tert-Butyl)-2-hydroxybenzaldehyde (4)}

Prepared as described in previous work [24]. ${ }^{1} \mathrm{H}$ NMR $\left(400 \mathrm{MHz}, \mathrm{CDCl}_{3}\right) \delta 11.77(\mathrm{~s}, 1 \mathrm{H}), 9.85(\mathrm{~s}, 1 \mathrm{H}), 7.52(\mathrm{~d}, J=$ $7.7 \mathrm{~Hz}, 1 \mathrm{H}), 7.39$ (d, $J=7.7 \mathrm{~Hz}, 1 \mathrm{H}), 7.00-6.95$ (m, 1H), 1.45 (s, 9H).

\section{3-(tert-Butyl)-2-hydroxy-5-nitrobenzaldehyde (5)}

Prepared by a modified literature procedure [25]. To a stirred solution of 3-(tert-butyl)-2-hydroxybenzaldehyde (1.0 g, $4.5 \mathrm{mmol})$ in glacial acetic acid $(20 \mathrm{~mL})$ was added $3.3 \mathrm{M}$ nitric acid $(4.0 \mathrm{~mL})$. The solution was heated to reflux for 30 minutes. After cooling to room temperature, the solution was poured onto ice. The resulting precipitate was filtered and washed with water, giving 3-(tert-butyl)-2-hydroxy-5-nitrobenzaldehyde $(0.9 \mathrm{~g}, 71 \%)$ as a yellow powder. ${ }^{1} \mathrm{H} \mathrm{NMR}\left(400 \mathrm{MHz}, \mathrm{CDCl}_{3}\right)$ $\delta 12.43(\mathrm{~s}, 1 \mathrm{H}), 9.96(\mathrm{~s}, 1 \mathrm{H}), 8.43-8.35(\mathrm{~m}, 2 \mathrm{H}), 1.45(\mathrm{~s}, 9 \mathrm{H})$.

\section{3-(tert-Butyl)-5-(dimethylamino)-2-hydroxybenzalde-} hyde (6)

Prepared by a modified literature procedure [28]. Pd/C (10\%, $100 \mathrm{mg}$ ) was added to a solution of 3-(tert-butyl)-2-hydroxy-5nitrobenzaldehyde 5 (200 $\mathrm{mg}, 0.9 \mathrm{mmol})$ and $40 \%$ aqueous formaldehyde $(4.5 \mathrm{~mL})$ in ethanol $(20 \mathrm{~mL})$. The reaction mixture was stirred under 1 bar of hydrogen at room temperature for 24 hours. Then, the $\mathrm{Pd} / \mathrm{C}$ was removed by filtration on celite, the volume of the filtrate was reduced by half under reduced pressure. Distilled water was added to the solution, resulting in formation of an orange precipitate (140 mg, 70\%), which was filtered and washed with water $(10 \mathrm{~mL})$ and cold ethanol. ${ }^{1} \mathrm{H}$ NMR $\left(400 \mathrm{MHz}, \mathrm{CDCl}_{3}\right) \delta 11.27(\mathrm{~s}, 1 \mathrm{H}), 9.83(\mathrm{~s}$, $1 \mathrm{H}), 7.14(\mathrm{~s}, 1 \mathrm{H}), 6.71(\mathrm{~s}, 1 \mathrm{H}), 2.88(\mathrm{~s}, 6 \mathrm{H}), 1.41(\mathrm{~s}, 9 \mathrm{H})$; ${ }^{13} \mathrm{C}$ NMR $\left(101 \mathrm{MHz}, \mathrm{CDCl}_{3}\right) \delta 197.28,154.37,144.05,138.97$, $122.84,120.34,114.90,42.07,35.14,29.22$; mp $130-131{ }^{\circ} \mathrm{C}$ (lit. [28] $134{ }^{\circ} \mathrm{C}$ ).

\section{6,6'-((1E,1'E)-((1R,2R)-Cyclohexane-1,2- diylbis(azanylylidene))bis(methanylylidene))bis(2- (tert-butyl)-4-(dimethylamino)phenol) (7)}

Prepared by a modified literature procedure [30]. A solution of $(1 R, 2 R)$-diaminocyclohexane $(64 \mathrm{mg}, 0.57 \mathrm{mmol})$ in ethanol $(5 \mathrm{~mL})$ was added dropwise to a solution of $6(250 \mathrm{mg}$, $1.13 \mathrm{mmol})$ in ethanol $(15 \mathrm{~mL})$. The resulting mixture was refluxed for 4 hours. After cooling to room temperature, distilled water $(30 \mathrm{~mL})$ was added. The resulting precipitate was filtered, washed with water and a small amount of cold ethanol to give a yellow powder (250 mg, 85\%). ${ }^{1} \mathrm{H} \mathrm{NMR}\left(400 \mathrm{MHz}, \mathrm{CDCl}_{3}\right) \delta$ $8.23(\mathrm{~s}, 2 \mathrm{H}), 6.88(\mathrm{~d}, J=3.0 \mathrm{~Hz}, 2 \mathrm{H}), 6.41(\mathrm{~d}, J=3.0 \mathrm{~Hz}, 2 \mathrm{H})$, 3.35-3.18 (m, 2H), $2.74(\mathrm{~s}, 12 \mathrm{H}), 2.00-1.90(\mathrm{~m}, 4 \mathrm{H})$, 1.79-1.72 (m, 2H), 1.47-1.43 (m, 2H), $1.38(\mathrm{~s}, 18 \mathrm{H}) ; \mathrm{mp}$ 106-110 ${ }^{\circ} \mathrm{C} ;\left[\alpha_{\mathrm{D}}\right]-225$ ( c 0.01, MeOH); ESIMS $m / z:[\mathrm{M}+\mathrm{H}]^{+}$ calcd for $\mathrm{C}_{32} \mathrm{H}_{48} \mathrm{~N}_{4} \mathrm{O}_{2}, 521.38$; found, 521.39.

\section{$5,5^{\prime}-\left(\left(1 E, 1^{\prime} E\right)-((1 R, 2 R)-C y c l o h e x a n e-1,2-\right.$ diylbis(azanylylidene))bis(methanylylidene))bis(3- (tert-butyl)-4-hydroxy- $\mathrm{N}, \mathrm{N}, \mathrm{N}$-trimethylbenzen- aminium iodide) (8a)}

To a solution of 7 (100 mg, $0.192 \mathrm{mmol})$ in dry acetonitrile ( $5 \mathrm{~mL}$ ) was added methyl iodide (271 $\mathrm{mg}, 1.92 \mathrm{mmol})$. The solution was stirred at room temperature for 24 hours. Diethyl ether $(10 \mathrm{~mL})$ was then added to the solution resulting in formation of a precipitate which was filtered and washed with ether to leave a bright yellow powder (146 mg, 95\%). ${ }^{1} \mathrm{H}$ NMR $\left(400 \mathrm{MHz}, \mathrm{DMSO}-d_{6}\right) \delta 8.59(\mathrm{~s}, 1 \mathrm{H}), 7.85(\mathrm{~d}, J=3.2 \mathrm{~Hz}, 1 \mathrm{H})$, 
$7.54(\mathrm{~d}, J=3.2 \mathrm{~Hz}, 1 \mathrm{H}), 3.58(\mathrm{~s}, 1 \mathrm{H}), 3,49$ (s, 9H), 1.88 (d, $J=$ $11.3 \mathrm{~Hz}, 1 \mathrm{H}), 1.78(\mathrm{~s}, 1 \mathrm{H}), 1.64(\mathrm{~s}, 1 \mathrm{H}), 1.46(\mathrm{~s}, 1 \mathrm{H}), 1.32$ (s, $9 \mathrm{H}) ;{ }^{13} \mathrm{C}$ NMR $\left(75 \mathrm{MHz}, \mathrm{CD}_{3} \mathrm{OD}\right) \delta 164.76,161.55,139.89$, $137.05,121.25,120.27,118.11,71.57,56.59,35.20,32.47$, 28.07, 23.83; mp 206-208 ${ }^{\circ} \mathrm{C}$; $\left[\alpha_{\mathrm{D}}\right]-175$ (c 0.01, MeOH); ESIMS $m / z$ : $[\mathrm{M}]^{2+}$ calcd for $\mathrm{C}_{34} \mathrm{H}_{54} \mathrm{~N}_{4} \mathrm{O}_{2}{ }^{2+}, 275.21$; found, 275.21 .

\section{5,5'-((1E,1'E)-((1R,2R)-Cyclohexane-1,2- diylbis(azanylylidene))bis(methanylylidene))bis $(N$ - benzyl-3-(tert-butyl)-4-hydroxy- $N, N$-dimethyl- benzenaminium bromide) (8b)}

To a solution of $7(120 \mathrm{mg}, 0.231 \mathrm{mmol})$ in dry acetonitrile $(5 \mathrm{~mL})$ was added benzyl bromide $(79 \mathrm{mg}, 0.46 \mathrm{mmol})$. The solution was stirred at room temperature for 24 hours. Diethyl ether $(10 \mathrm{~mL})$ was then added to the solution resulting in formation of a precipitate which was filtered and washed with ether to leave a bright yellow powder (165 mg, 78\%). ${ }^{1} \mathrm{H}$ NMR $\left(400 \mathrm{MHz}, \mathrm{CDCl}_{3}\right) \delta 9.00(\mathrm{~s}, 1 \mathrm{H}), 8.80(\mathrm{~d}, J=3.1 \mathrm{~Hz}, 1 \mathrm{H})$, 7.33-7.27 (m, 1H), 7.19-6.98 (m, 4H), $6.76(\mathrm{~d}, J=3.2 \mathrm{~Hz}, 1 \mathrm{H})$, 5.51-5.37 (s, 2H), 3.98-3.90 (m, 1H), $3.85(\mathrm{~d}, J=8.0 \mathrm{~Hz}, 6 \mathrm{H})$, $2.2-2.1(\mathrm{~m}, 1 \mathrm{H}), 2.0-1.9(\mathrm{~m}, 1 \mathrm{H}), 1.6-1.4(\mathrm{~m}, 2 \mathrm{H}), 1.25(\mathrm{~s}$, $9 \mathrm{H}) ;{ }^{13} \mathrm{C}$ NMR $\left(101 \mathrm{MHz}, \mathrm{DMSO}-d_{6}\right) \delta 165.63,162.37$, 139.22, 134.33, 133.01, 130.73, 129.06, 128.87, 123.76, 122.83, 117.57, 72.26, 69.97, 53.21, 35.55, 32.51, 29.37, 29.04, 24.05; mp 140-144 ${ }^{\circ} \mathrm{C}$; $\left[\alpha_{\mathrm{D}}\right] 107$ (c 0.05, MeOH); ESIMS $m / z$ : $[\mathrm{M}]^{2+}$ calcd for $\mathrm{C}_{46} \mathrm{H}_{62} \mathrm{~N}_{4} \mathrm{O}_{2}{ }^{2+}$, 351.24; found, 351.24.

\section{Aluminium-salen complex (1)}

To a solution of $\mathbf{8 a}(113 \mathrm{mg}, 0.14 \mathrm{mmol})$ in dry acetonitrile $(5 \mathrm{~mL})$ under argon was added diethylaluminum chloride ( $0.14 \mathrm{~mL}, 1 \mathrm{M}$ solution in hexane). The reaction mixture was heated at reflux for 3 hours. The solvent was evaporated under reduced pressure to give a dark yellow powder (95 mg, 78\%) which was used without any additional purification. ${ }^{1} \mathrm{H}$ NMR (400 MHz, DMSO- $\left.d_{6}\right) \delta 8.46(\mathrm{~s}, 1 \mathrm{H}), 8.10(\mathrm{~s}, 1 \mathrm{H}), 7.66(\mathrm{~s}, 1 \mathrm{H})$, $3.55(\mathrm{~s}, 9 \mathrm{H}), 3.38(\mathrm{~s}, 1 \mathrm{H}), 2.55(\mathrm{~s}, 1 \mathrm{H}), 1.94(\mathrm{~s}, 1 \mathrm{H}), 1.50(\mathrm{~s}$, 9H), $1.44(\mathrm{~s}, 1 \mathrm{H}), 1.33(\mathrm{~s}, 1 \mathrm{H}) ; \mathrm{mp}>300{ }^{\circ} \mathrm{C} ;\left[\alpha_{\mathrm{D}}\right]-109.5(\mathrm{c}$ 0.05, MeOH); ESIMS $m / z$ : $[\mathrm{M}]^{2+}$ calcd for $\mathrm{C}_{34} \mathrm{H}_{52} \mathrm{AlClN}_{4} \mathrm{O}_{2}{ }^{2+}$, 305.18; found, 296.19 (substitution of $\mathrm{Cl}$ by $\mathrm{OH}$ ); 303.20 (substitution of $\mathrm{Cl}$ by $\mathrm{OMe}$ ).

\section{Aluminium-salen complex (2)}

To a solution of $\mathbf{8 b}$ (140 $\mathrm{mg}, 0.163 \mathrm{mmol})$ in dry acetonitrile $(5 \mathrm{~mL})$ under argon was added diethylaluminum chloride ( $0.17 \mathrm{~mL}, 1 \mathrm{M}$ solution in hexane). The reaction mixture was refluxed for 3 hours. Then, the solvent was evaporated under reduced pressure to give a dark yellow powder (136 mg, 91\%) which was used without any additional purification. ${ }^{1} \mathrm{H}$ NMR $\left(400 \mathrm{MHz}, \mathrm{DMSO}-d_{6}\right) \delta 8.33(\mathrm{~s}, 1 \mathrm{H}), 7.83(\mathrm{~d}, J=3.0 \mathrm{~Hz}, 1 \mathrm{H})$ $7.47(\mathrm{t}, J=8.6 \mathrm{~Hz}, 1 \mathrm{H}), 7.40(\mathrm{~s}, 1 \mathrm{H}), 7.28(\mathrm{t}, J=7.7 \mathrm{~Hz}, 2 \mathrm{H})$, $7.02(\mathrm{~d}, J=7.3 \mathrm{~Hz}, 2 \mathrm{H}), 4.99$ (d, $J=7.5 \mathrm{~Hz}, 2 \mathrm{H}), 3.55$ (d, $J=$ $7.3 \mathrm{~Hz}, 6 \mathrm{H}), 3.35$ (s, 1H) 1.89 (s, 2H), 1.48 (d, $J=4.5 \mathrm{~Hz}$, $11 \mathrm{H}) ; \mathrm{mp}>300{ }^{\circ} \mathrm{C} ;\left[\alpha_{\mathrm{D}}\right]-83.4(c 0.01, \mathrm{MeOH})$; ESIMS $m / z$ : $[\mathrm{M}]^{2+}$ calcd for $\mathrm{C}_{46} \mathrm{H}_{60} \mathrm{AlClN}_{4} \mathrm{O}_{2}{ }^{2+}$, 381.21; found, 372.22 (substitution of $\mathrm{Cl}$ by $\mathrm{OH}$ ); 379.20 (substitution of $\mathrm{Cl}$ by $\mathrm{OMe})$.

\section{Aluminium-salen complex (10)}

Prepared as described in previous work [29]. ${ }^{1} \mathrm{H}$ NMR (400 MHz, DMSO- $d_{6}$ ) $\delta 8.35(\mathrm{~s}, 1 \mathrm{H}), 7.41(\mathrm{~d}, J=2.4 \mathrm{~Hz}, 1 \mathrm{H})$, $7.36(\mathrm{~d}, J=2.4 \mathrm{~Hz}, 1 \mathrm{H}), 2.60$ (d, $J=10.7 \mathrm{~Hz}, 1 \mathrm{H}), 1.99-1.90$ (s, 1H), $1.53(\mathrm{~s}, 9 \mathrm{H}), 1.40-1.20(\mathrm{~m}, 3 \mathrm{H}), 1.29(\mathrm{~s}, 9 \mathrm{H})$.

\section{Synthesis of cyclic carbonates}

All cyclic carbonate formations were carried out in autoclaves or, in case of 1 bar $\mathrm{CO}_{2}$ reactions, in sample vials with a balloon of $\mathrm{CO}_{2}$ attached to them. In both cases the reactions were magnetically stirred. After completion of the experiment, the reaction mixture was analysed by ${ }^{1} \mathrm{H}$ NMR spectroscopy and passed through a pad of silica to separate the catalyst. In the case of a $100 \%$ conversion, $\mathrm{CH}_{2} \mathrm{Cl}_{2}$ was used as the eluent, if the conversion was incomplete then column chromatography was used to purify the compounds $\left(\mathrm{SiO}_{2}, \mathrm{EtOAc} /\right.$ hexane, 1:3).

Styrene carbonate: ${ }^{1} \mathrm{H}$ NMR $\left(400 \mathrm{MHz}, \mathrm{CDCl}_{3}\right) \delta$ $7.44-7.32(\mathrm{~m}, 5 \mathrm{H}), 5.66(\mathrm{t}, J=8.0 \mathrm{~Hz}, 1 \mathrm{H}), 4.82-4.73(\mathrm{~m}, 1 \mathrm{H})$, 4.37-4.26 (m, 1H); ${ }^{13} \mathrm{C}$ NMR $\left(101 \mathrm{MHz}, \mathrm{CDCl}_{3}\right) \delta 155.00$, $135.88,129.80,129.31,126.00,78.11,71.28$.

4-Chlorostyrene carbonate: ${ }^{1} \mathrm{H}$ NMR $\left(400 \mathrm{MHz}, \mathrm{CDCl}_{3}\right) \delta$ $7.48-7.25(\mathrm{~m}, 4 \mathrm{H}), 5.65(\mathrm{t}, J=8.0 \mathrm{~Hz}, 1 \mathrm{H}), 4.79$ (t, $J=8.2 \mathrm{~Hz}$, $1 \mathrm{H}), 4.29(\mathrm{dd}, J=8.6,7.9 \mathrm{~Hz}, 1 \mathrm{H}) ;{ }^{13} \mathrm{C} \mathrm{NMR}(101 \mathrm{MHz}$, $\left.\mathrm{CDCl}_{3}\right) \delta 154.65,135.85,134.35,129.59,127.37,77.34,71.10$.

3-Chloropropylene carbonate: ${ }^{1} \mathrm{H} \mathrm{NMR}\left(400 \mathrm{MHz}, \mathrm{CDCl}_{3}\right) \delta$ 5.02-4.93 (m, 1H), 4.60-4.53 (m, 1H), $4.37(\mathrm{dd}, J=8.9$, $5.7 \mathrm{~Hz}, 1 \mathrm{H}), 3.82-3.67(\mathrm{~m}, 2 \mathrm{H}) ;{ }^{13} \mathrm{C} \mathrm{NMR}\left(101 \mathrm{MHz}, \mathrm{CDCl}_{3}\right)$ $\delta 154.49,74.48,67.06,44.03$.

3-Phenoxypropylene carbonate: ${ }^{1} \mathrm{H} \mathrm{NMR}\left(400 \mathrm{MHz}, \mathrm{CDCl}_{3}\right)$ 反 7.37-6.84 (m, 5H), 5.08-4.94 (m, 1H), 4.63-4.46 (m, 2H), 4.30-4.06 (m, 2H); ${ }^{13} \mathrm{C}$ NMR (101 MHz, $\left.\mathrm{CDCl}_{3}\right) \delta 157.83$, $154.76,129.78,122.08,114.69,74.20,66.95,66.32$.

Propylene carbonate: ${ }^{1} \mathrm{H}$ NMR $\left(400 \mathrm{MHz}, \mathrm{CDCl}_{3}\right) \delta$ 4.92-4.67 (m, 1H), 4.64-4.38 (m, 1H), 4.07-3.89 (m, 1H), $1.47-1.36(\mathrm{~m}, 3 \mathrm{H}) ;{ }^{13} \mathrm{C} \mathrm{NMR}\left(101 \mathrm{MHz}, \mathrm{CDCl}_{3}\right) \delta 155.22$, $73.74,70.78,19.45$.

1,2-Hexylene carbonate: ${ }^{1} \mathrm{H}$ NMR $\left(400 \mathrm{MHz}, \mathrm{CDCl}_{3}\right) \delta$ $4.74-4.59(\mathrm{~m}, 1 \mathrm{H}), 4.53-4.43(\mathrm{~m}, 1 \mathrm{H}), 4.02(\mathrm{dt}, J=9.9,4.9 \mathrm{~Hz}$, 
1H), 1.82-1.57 (m, 2H), 1.46-1.20 (m, 4H), 0.92-0.81 (m, 3H); ${ }^{13} \mathrm{C}$ NMR $\left(101 \mathrm{MHz}, \mathrm{CDCl}_{3}\right) \delta 155.24,77.20,69.51,33.59$, $26.49,22.31,13.86$.

3-Hydroxypropylene carbonate: ${ }^{1} \mathrm{H} \mathrm{NMR}\left(400 \mathrm{MHz}, \mathrm{CDCl}_{3}\right)$ $\delta 4.90-4.73(\mathrm{~m}, 1 \mathrm{H}), 4.59-4.39(\mathrm{~m}, 2 \mathrm{H}), 3.96(\mathrm{dt}, J=20.4$, $10.2 \mathrm{~Hz}, 1 \mathrm{H}), 3.68(\mathrm{td}, J=13.1,5.5 \mathrm{~Hz}, 1 \mathrm{H}), 2.84-2.56$ $(\mathrm{m}, 1 \mathrm{H}) ;{ }^{13} \mathrm{C} \mathrm{NMR}\left(101 \mathrm{MHz}, \mathrm{CDCl}_{3}\right) \delta 155.38,76.64,65.85$, 61.73 .

1,2-Butylene carbonate: ${ }^{1} \mathrm{H}$ NMR $\left(400 \mathrm{MHz}, \mathrm{CDCl}_{3}\right) \delta$ $4.71-4.55(\mathrm{~m}, 1 \mathrm{H}), 4.48(\mathrm{t}, J=8.1 \mathrm{~Hz}, 1 \mathrm{H}), 4.04(\mathrm{dd}, J=8.4$, $7.0 \mathrm{~Hz}, 1 \mathrm{H}), 1.85-1.63(\mathrm{~m}, 2 \mathrm{H}), 1.03-0.89(\mathrm{~m}, 3 \mathrm{H}) ;{ }^{13} \mathrm{C} \mathrm{NMR}$ $\left(101 \mathrm{MHz}, \mathrm{CDCl}_{3}\right) \delta 155.27,78.16,69.13,26.95,8.52$.

\section{Synthesis of polycyclohexene carbonate}

Prepared as reported above for the synthesis of cyclic carbonates at 10-35 bar $\mathrm{CO}_{2}$, but without any additional purification of the reaction product. ${ }^{1} \mathrm{H}$ NMR $\left(400 \mathrm{MHz}, \mathrm{CDCl}_{3}\right) \delta$ 4.71-4.56 (broad, 2H), 2.21-2.04 (broad, 4H), $1.79-1.62$ (broad, $4 \mathrm{H})$.

\section{Acknowledgements}

The authors thank the Royal Society for an Anglo-Russian collaboration grant under the international exchange scheme.

\section{References}

1. Aresta, M.; Dibenedetto, A.; Angelini, A. Chem. Rev. 2014, 114, 1709-1742. doi:10.1021/cr4002758

2. Schäffner, B.; Schäffner, F.; Verevkin, S. P.; Börner, A. Chem. Rev. 2010, 110, 4554-4581. doi:10.1021/cr900393d

3. Sakakura, T.; Kohno, K. Chem. Commun. 2009, 1312-1330. doi:10.1039/b819997c

4. Takata, T.; Furusho, Y.; Murakawa, K.-i.; Endo, T.; Matsuoka, H.; Hirasa, T.; Matsuo, J.; Sisido, M. J. Am. Chem. Soc. 1998, 120, 4530-4531. doi:10.1021/ja974337।

5. Nicolaou, K. C.; Yang, Z.; Liu, J. J.; Ueno, H.; Nantermet, P. G.; Guy, R. K.; Claiborne, C. F.; Renaud, J.; Couladouros, E. A.; Paulvannan, K.; Soresen, E. J. Nature 1994, 367, 630-634. doi:10.1038/367630a0

6. Chang, H.-T.; Sharpless, K. B. Tetrahedron Lett. 1996, 37, 3219-3222. doi:10.1016/0040-4039(96)00534-5

7. He, Q.; O'Brien, J. W.; Kitselman, K. A.; Tompkins, L. E.; Curtis, G. C. T.; Kerton, F. M. Catal. Sci. Technol. 2014, 4, 1513-1528. doi:10.1039/c3cy00998j

8. Martín, C.; Fiorani, G.; Kleij, A. W. ACS Catal. 2015, 5, 1353-1370. doi: $10.1021 / \operatorname{cs} 5018997$

9. Comerford, J. W.; Ingram, I. D. V.; North, M.; Wu, X. Green Chem. 2015, 17, 1966-1987. doi:10.1039/C4GC01719F

10. Ikpo, N.; Flogeras, J. C.; Kerton, F. M. Dalton Trans. 2013, 42, 8998-9006. doi:10.1039/c3dt00049d

11. Taherimehr, M.; Pescarmona, P. P. J. Appl. Polym. Sci. 2014, 131, 41141. doi:10.1002/app.41141

12. Decortes, A.; Castilla, A. M.; Kleij, A. W. Angew. Chem., Int. Ed. 2010, 49, 9822-9837. doi:10.1002/anie.201002087
13. North, M.; Pasquale, R.; Young, C. Green Chem. 2010, 12, 1514-1539. doi:10.1039/c0gc00065e

14. Tian, D.; Liu, B.; Gan, Q.; Li, H.; Darensbourg, D. J. ACS Catal. 2012, 2, 2029-2035. doi:10.1021/cs300462r

15. Meléndez, J.; North, M.; Villuendas, P. Chem. Commun. 2009, 2577-2579. doi:10.1039/b900180h

16. Ren, W.-M.; Liu, Y.; Lu, X.-B. J. Org. Chem. 2014, 79, 9771-9777. doi:10.1021/jo501926p

17. Hanhart, W.; Ingold, C. K. J. Chem. Soc. 1927, 997-1020. doi:10.1039/jr9270000997

18. Hughes, E. D.; Ingold, C. K.; Patel, C. S. J. Chem. Soc. 1933, 526-530. doi:10.1039/jr9330000526

19. de la Zerda, J.; Neumann, R.; Sasson, Y. J. Chem. Soc., Perkin Trans. 2 1986, 823-826. doi:10.1039/p29860000823

20. Hofman, A. W. Proc. R. Soc. London 1859, 10, 594-596. doi:10.1098/rspl.1859.0121

21. Collie, N.; Schryver, S. B. J. Chem. Soc., Trans. 1890, 57, 767-782. doi:10.1039/ct8905700767

22. Zaki, A.; Fahim, H. J. Chem. Soc. 1942, 270-272. doi:10.1039/jr9420000270

23. Gordon, J. E. J. Org. Chem. 1965, 30, 2760-2763. doi:10.1021/jo01019a060

24. Gisch, N.; Balzarini, J.; Meier, C. J. Med. Chem. 2007, 50, 1658-1667. doi:10.1021/jm0613267

25. Braun, M.; Fleischer, R.; Mai, B.; Schneider, M.-A.; Lachenicht, S. Adv. Synth. Catal. 2004, 346, 474-482. doi:10.1002/adsc. 200303178

26. Chen, C.-T.; Kao, J.-Q.; Salunke, S. B.; Lin, Y.-H. Org. Lett. 2011, 13, 26-29. doi:10.1021/ol1024053

27. Sun, M.; Mu, Y.; Wu, Q.; Gao, W.; Ye, L. New J. Chem. 2010, 34, 2979-2987. doi:10.1039/c0nj00439a

28. Waibel, M.; Hasserodt, J. Tetrahedron Lett. 2009, 50, 2767-2769. doi:10.1016/j.tetlet.2009.03.139

29. Sigman, M. S.; Jacobsen, E. N. J. Am. Chem. Soc. 1998, 120, 5315-5316. doi:10.1021/ja980299+

30. Chiang, L.; Kochem, A.; Jarjayes, O.; Dunn, T. J.; Vezin, H.; Sakaguchi, M.; Ogura, T.; Orio, M.; Shimazaki, Y.; Thomas, F.; Storr, T. Chem. - Eur. J. 2012, 18, 14117-14127. doi:10.1002/chem.201201410

31. North, M. ARKIVOC 2012, (i), 610-628.

32. Beattie, C.; North, M.; Villuendas, P.; Young, C. J. Org. Chem. 2013, 78, 419-426. doi:10.1021/jo302317w

33. Darensbourg, D. J.; Billodeaux, D. R. Inorg. Chem. 2005, 44 , 1433-1442. doi:10.1021/ic048508g

34. Sugimoto, $\mathrm{H}$.; H. Ohtsuka, H.; Inoue, $\mathrm{S}$ J. Polym. Sci., Part A: Polym. Chem. 2005, 43, 4172-4186. doi:10.1002/pola.20894

35. Chapman, A. M.; Keyworth, C.; Kember, M. R.; Lennox, A. J. J.; Williams, C. K. ACS Catal. 2015, 5, 1581-1588. doi:10.1021/cs501798s 


\section{License and Terms}

This is an Open Access article under the terms of the Creative Commons Attribution License

(http://creativecommons.org/licenses/by/2.0), which permits unrestricted use, distribution, and reproduction in any medium, provided the original work is properly cited.

The license is subject to the Beilstein Journal of Organic Chemistry terms and conditions:

(http://www.beilstein-journals.org/bjoc)

The definitive version of this article is the electronic one which can be found at:

doi:10.3762/bjoc.11.176 